\title{
Use of Intra Uterine Devices in Family Planning
}

\author{
Argia Rasmadewi Bakri \\ Medical Faculty, Hasanuddin University, Indonesia \\ Received: August 2, 2020 \\ Received in Revised: August 10, 2020 \\ Accepted August 13, 2020
}

\begin{abstract}
Contraception is generally divided into two types, namely the Long Term Contraception Method (MKJP) and the Non Long Term Contraception Method (Non MKJP). Side effects of using injection contraceptives; There is a change in menstrual pattern, such as irregularity, bleeding, spotting, or bleeding for up to 10 days. Intra Uterine Devices (IUD) are long-term contraceptives that are inserted into the uterus. The advantages of this contraception include high effectiveness of about 0.6 to 0.8 pregnancies per 100 women, failure in 125 to 170 pregnancies. There are several disadvantages to its use, such as bleeding (spotting) between menstruation, excessive menstrual pain, longer menstrual periods, and heavy bleeding at the time of menstruation.
\end{abstract}

Keywords: Intra Uterine Devices (IUD), Contraception, Side Effect.

\section{Introduction}

Family planning $(\mathrm{KB})$ is an effort to regulate child birth, distance and ideal age of delivery, regulate pregnancy, through promotion, protection and assistance in accordance with reproductive rights to create a quality family (Aminuddin, 2016). The term contraception comes from the words cons and conception. Contra which means fighting or preventing while conception is fertilization or fertilization. So that, contraception is an effort to prevent the meeting between the ovum and sperm, so that the ovum is not fertilized resulting in pregnancy.

Contraception is the prevention of fertilization of an egg by a sperm cell or prevention of sticking a fertilized egg to the uterine wall (Aminuddin, 2016) Family planning acceptors are fertile age couples (PUS) who use one of the contraceptive tools/drugs (BKKBN) (BKKBN, 2018). The IUD is a contraceptive with high effectiveness in preventing pregnancy and for spacing pregnancies. The copper content (Cuprum) in Copper $\mathrm{T}$ can thicken the cervical mucus so that the mobilization of sperm cells is inhibited to go to the fallopian tube (Pratama, 2016).

According to the BKKBN, active family planning among PUS in 2018 amounted to $63.27 \%$, almost the same as in 2017 which was $63.22 \%$. Meanwhile, the RPJMN target to be achieved in 2019 is $66 \%$. The results of the 2017 IDHS also showed the same figure for active family planning, namely $63.6 \%$. Based on the pattern in choosing the type of contraception, most active contraceptives chose injections and pills as contraceptives. They were even more dominant (more than $80 \%$ ) compared to other methods, namely injections $(63.71 \%)$ and pills (17.24\%), IUD ( $7.35 \%)$, Implants (7.2\%). The method for MOP that was least used by family planning participants was the male surgery method (MOP) as much as $0.5 \%$, then the female surgery method (MOW) as much as $2.76 \%$ and condoms as much as $1.24 \%$. (Indonesian Ministry of Health, 2018). For South Sulawesi Province, in 2018 KB was active, 
namely $61.66 \%$. In 2015 , the contraceptive method most used by active family planning participants was injection $(51.44 \%)$ and the second largest was the pill $(29.99 \%)$, IUD (3.38\%), implants $(7.22 \%)$ while the The contraceptive that is least chosen by active family planning participants is the Male Operation Method (MOP), which is $0.11 \%$, then the rest is 0.01\%. (South Sulawesi Health Office, 2015).

Contraception is generally divided into two types, namely the Long Term Contraception Method (MKJP) and the Non Long Term Contraception Method (Non MKJP). MKJP includes implantable contraceptive types, intra-uterine devices (IUD) or intrauterine contraceptive devices (IUD), male operative methods (MOP) such as vasectomy, and female operative methods (MOW) such as tubectomy. Meanwhile, Non MKJP includes condoms, birth control pills, injections, and other methods other than MKJP. (Primary, 2016)

IUD is a contraceptive that is inserted into the uterus made of polyethylene with or without metals or steroids. The IUD is very effective at spacing pregnancies compared to other longterm contraceptive methods such as implants, tubectomy, and vasectomy. The implant capsule is placed just under the skin over the fold of the elbow, in the medial area of the upper arm.

Tubectomy is any action on both female fallopian tubes that results in the woman not having any more offspring. Sterilization can also be done in men, namely vasectomy. Thus, if one partner has undergone sterilization, conventional contraceptives are no longer needed. The most important factor in the implementation of sterilization is the volunteerism of acceptors. Sterilization should not be carried out on unmarried / unmarried women, couples who are not harmonious or marital relationships that are at risk of divorce, and couples who are still hesitant to receive sterilization.

Vasectomy is a clinical procedure to stop the male reproductive capacity by performing occlusion of the vasa deferensia so that the flow of sperm transport is blocked and the fertilization process (fusion with the ovum) does not occur. Complications that can occur during the procedure or some time after the procedure. Complications during the procedure can include complications due to anaphylactic reactions caused by using lidocaine or excessive manipulation of the vein webbing around the vasa deferensia. Post-treatment complications may include infectious scrotal hematoma or testicular abscess, congestive epididymitis, or chronic inflammation of the granuloma at the incision site (Ramli, 2020).

\section{Non Long Term Contraceptive Method (Non MKJP)}

A thin rubber bag condom, usually made of latex, is non-porous, used to cover the stretched (tense) penis before inserting it into the vaginal canal. The advantages are easy to obtain at pharmacies, drug stores, or supermarkets at affordable prices and easy to carry everywhere, everyone can use without experiencing side effects. Condoms come in a variety of shapes and aromas, and are not scattered and easy to throw away. Whereas the diaphragm is a condom used on women, but in reality it is less popular in society. (Maximum, 2019).

Contraceptive injection is a way of contraception by way of injection in an attempt to prevent pregnancy through hormonal injections. In Indonesia, injectable hormonal contraceptives are increasingly being used because of their effective work, practical use, and relatively cheap and safe prices. Before injecting, the mother's health must be checked first to ensure its suitability. The injection is given when the mother is not pregnant. In general, the use of birth control injections has the same requirements as the use of pills. 
As for the benefits of using injection contraceptives, namely, the effectiveness is $99 \%$ $99.6 \%$, the risk to health is small, does not affect the relationship between husband and wife, no internal examination is required, can prevent pregnancy outside the uterus, uterine cancer, breast cancer, patients do not need to save injectable drugs, and does not affect breast milk. In general, family planning acceptors prefer the injection contraceptive method for practical reasons, namely simple and need not be afraid of forgetting. Injectable contraceptives have high effectiveness when injections are carried out regularly and according to a predetermined schedule.

Time of injection contraceptive administration after delivery, 3-5 days after delivery and after breastfeeding, after a miscarriage (immediately after curettage or 30 days after miscarriage), as long as the mother is not pregnant again, and during menstruation (day one to day 5 menstrual period). The location of the injection is the buttocks / buttocks area and the upper arm muscle area.

Side effects of using injection contraceptives; There is a change in menstrual pattern, such as irregularity, bleeding, spotting, or bleeding for up to 10 days; Nausea, headache, mild breast pain, and these complaints will disappear after the second or third injection; There can be serious side effects, such as heart attack, stroke, blood clots in the lungs or brain and possible liver tumors; Weight gain, hair loss, bone loss, fat metabolism disorders; Possible delay in fertility restoration after discontinuation of use; Can increase fungal infections around the genitals; Does not guarantee protection against the spread of Hepatitis B, or infection with the HIV virus

There are 2 contra indications for injection contraception, namely absolute, namely in pregnant women, a history of breast cancer or reproductive organs and vaginal bleeding of unknown cause; and relative, namely a history of mental disorders, a history of breast disease, a history of headaches, and a woman who wants to get pregnant earlier (Darmawati, 2011).

\section{Intra Uterine Devices (IUD)}

The IUD is a long-term contraceptive that is inserted into the uterus made of elastic plastic wrapped in copper or a mixture of copper and silver (Pratama, 2016). IUD can be divided into four types: (1) Copper-T, Copper-7, Multi Load, Lippes Loop (Pratama, 2016).

IUD / IUD causes anti-fertility reactions with a duration of use between 2-10 years with its method of action inhibiting the ability of sperm to enter the fallopian tube, affecting fertilization before the ovum reaches the uterine cavity, preventing sperm and ovum from meeting because their passage is blocked, and allowing for preventing implantation eggs in the uterus (Pratama, 2016). There are two IUDs, namely hormonal IUD / progestin IUD and non Hormonal IUD. The way the IUD works by causing an endometrial inflammatory reaction accompanied by an invasion of inflammatory cells / leukocytes that can destroy both the blastocyst and sperm. (Princess, 2017)

An indication for the use of an IUD is that the insertion of an IUD is intended for women who already have one or more live children. Want to space out the pregnancy. It is enough for the child to live, not to want to get pregnant again, but to fear or refuse permanent methods. Not suitable or not suitable to use hormonal contraception (suffering from heart disease, hypertension, liver) (Pipit, 2016)

In using the IUD, there are several side effects and conditions that are not allowed to use the IUD. Conditions that are not allowed to use the IUD include pregnancy, bleeding disorders, inflammation of the genitals, suspected malignant tumors of the genitals, benign uterine 
tumors, congenital abnormalities of the uterus, inflammation of the pelvis, abnormal uterine bleeding, carcinoma of the pelvic organs, malformations. pelvis, uterine myoma especially submucosa, severe dysmenorrhea, cervical canal stenosis, severe anemia and blood coagulation disorders, and rheumatic heart disease (Pratama, 2016).

Contraindications to insertion of an IUD should not be used in women who are pregnant or suspected of being pregnant. Occurrence of unknown vaginal bleeding. Are suffering from genital infection (vaginitis, cervicitis), genital cancer, malignant trophoblast disease, and pelvic tuberculosis. In the last three months experiencing or frequently suffering from pelvic inflammatory disease or septic abortion. Experiencing abnormal uterine congenital abnormalities or benign tumors of the uterus that can affect the uterine cavity. And women who have a uterine cavity size of less than $5 \mathrm{~cm}$ (Pipit, 2016).

\section{Effectiveness and Benefits of the IUD}

Several studies have shown that there are advantages of using this contraceptive, including: high effectiveness of about 0.6 to 0.8 pregnancies per 100 women, failure in 125 to 170 pregnancies, immediately effective when inserted in the uterus, does not require repeat visits, does not affect sexual intercourse, does not have hormonal side effects, does not affect the quality and volume of breast milk, can be inserted immediately after delivery or after abortion, provided there is no infection, helps prevent ectopic pregnancy, does not interact with drugs, can be used until menopause (Saifuddin, 2013).

\section{Disadvantages and side effects of the IUD}

In addition to the effectiveness of using the IUD, there are several disadvantages to its use, such as intermenstrual bleeding (spotting), excessive menstrual pain, longer menstrual periods, and heavy bleeding during menstruation. These things allow anemia and other risks. (Primary, 2016)

The side effects of using the IUD include; (1) Spotting: spotting of blood between menstrual cycles, spotting will appear when you are tired and stressed. Active women often experience spotting when using IUD contraceptives, (2) Changes in the menstrual cycle: after insertion of the IUD, menstrual cycles are shorter. Menstrual cycles that appear faster than normal cycles on average, namely 28 days with a menstrual length of three to seven days, usually the menstrual cycle will change to 21 days, (3) Amenorrhea: no signs of menstruation for three months or more. Handling the side effects of amenorrhea is checking whether you are pregnant or not. If not, provide counseling and investigate the cause of amenorrhea if desired with the IUD not removed. Meanwhile, if pregnant, explain and advise to remove the IUD if the strings are visible and the pregnancy is less than 13 weeks. If the strings are not visible or the pregnancy is more than 13 weeks, the IUD cannot be removed. Patients who are pregnant and want to maintain their pregnancy without removing the IUD can be given an explanation of the risk of possible pregnancy failure and infection, and the development of pregnancy should be observed and considered, (4) Dysmenorrhea: the appearance of menstrual pain without an organic cause. The management of dysmenorrhea is to confirm and confirm the presence of pelvic inflammatory disease (PID) and other causes of abdominal muscle cramps, and to overcome the causes if found. Give analgesics if no cause is found to ease the pain a little. Patients who are experiencing severe abdominal muscle cramps should remove the IUD and help the patient determine a different method of contraception. (5) Menorrhagia: excessive heavy bleeding during menstruation or menstruation (menstrual period more than eight days). Confirm and confirm the presence of pelvic infection and ectopic 
pregnancy. If there are no pathological abnormalities, continued bleeding and heavy bleeding, then do counseling and monitoring. Pharmacological therapy for menorrhagia can use Ibuprofen to reduce bleeding and give iron tablets. The IUD may be removed if the patient wishes, if the patient has been wearing the IUD for more than three months and is known to be anemic with an $\mathrm{Hb}<7 \mathrm{~g} / \mathrm{dl}$ it is recommended to remove the IUD and help choose another suitable method, (6) Fluor Albus: use of the IUD will trigger recurrence of bacterial vaginosis, which is an abnormal condition in the vaginal ecosystem caused by increased growth of anaerobic bacterial vaginal flora to replace Lactobacillus which has a high concentration as normal vaginal flora, (7) Post sexual bleeding: this post sexual bleeding is caused by the position of the IUD thread rubbing against the cervix or the wall vaginal bleeding, but the amount of bleeding that appears is only a small amount, in some cases this side effect justifies the acceptor to drop out, especially due to wrong encouragement from the husband (Pratama, 2016).

\section{Time to Insert and Remove the IUD}

The IUD can be inserted at any time in the menstrual cycle, which ensures that the client is not pregnant within the first to the 7 th day of the menstrual cycle. Immediately after delivery, during the first 48 hours or after 4 weeks postpartum. After suffering an abortion (immediately or within 7 days) if there are no symptoms of infection, and for 1 to 5 days after unprotected intercourse. An IUD can be inserted at any time during the menstrual cycle. At that time insertion will be easy because the cervical canal is slightly widened and the possibility of pregnancy is very small, the pain is less and the bleeding is not so much. An IUD can also be inserted postpartum. IUD. The IUD can be inserted at an interval between two menstrual periods. If it is inserted after ovulation, it should be ensured that women are not pregnant or those who have used other contraceptive methods. (Pipit, 2016)

In the intrauterine device (IUD), there are strings of threads to control it. These threads make it easier to remove the contraceptive and allow a woman to check herself periodically to see if the IUD is still in place. (Primary, 2016)

The time to remove the IUD is as needed and the copper-coated spiral contraceptive can prevent pregnancy for up to 10-12 years. This means that if the deadline is reached, it is better if you let go of spiral KB (Family planning).

\section{IUD Insertion Procedure}

The principle of inserting the IUD is to place it as high as possible in the uterine cavity (cavum uteri). The best time for insertion is when the mouth of the uterus is still open and the uterus is soft. For example, 40 days after delivery and at the end of menstruation.

\section{IUD expulsion}

IUD expulsion is the loss of the IUD from the uterus most commonly in the first month after insertion. Expulsion of the IUD is self-expulsion of the IUD from the uterus that can occur partially or completely. Expulsion usually occurs during menstruation and is influenced by the following, age and parity, at low parity 1 or 2 the probability of expulsion is two times greater than parity of 5 or more, as well as older women. The length of time using the IUD is also a cause of the expulsion. A history of expulsion of the IUD on previous insertion is likely to have repeated expulsions with a $50 \%$ chance. Maternal psychological factors with IUD can affect uterine mortality, so the frequency of expulsion is more often found in emotional and fearful women and those who are 
psychologically unstable. Therefore, it is important for women with psychologically unstable factors to be given adequate lighting before inserting an IUD (Pipit, 2016).

\section{Conclusion}

An indication for the use of an IUD is that the insertion of an IUD is intended for women who already have one or more live children. Want to space out the pregnancy. It is enough for the child to live, not to want to get pregnant again, but to fear or refuse permanent methods. insertion of an IUD should not be used in women who are pregnant or suspected of being pregnant. Occurrence of unknown vaginal bleeding. Are suffering from genital infection (vaginitis, cervicitis), genital cancer, malignant trophoblast disease, and pelvic tuberculosis. In the last three months experiencing or frequently suffering from pelvic inflammatory disease or septic abortion.

\section{References}

Aminuddin Sofyan, N. I. M. 2016. Problematika Penggunaan Alat Kontrasepsi Suntik 3 (Tiga) Bulan Pada Masyarakat Kec. Puuwatu Kota Kendari Ditinjau Dari Hukum Islam. Diss. Iain Kendari,

Darmawati. 2011. Factors Affect Reproductive Women Choose Contraceptive Injection. Maternity and Pediatric Nursing Department, School of Nursing, Faculty of Medicine, Syiah Kuala University, Banda Aceh.

Dinkes Provinsi Sulawesi Selatan, 2015 .Profil Kesehatan Sulawesi Selatan 2015

Habif, T. 2020. "Diaphragm Fitting, Insertion, and Removal." Advanced PracticeNursing Procedures 22.4: 246.

Kemenkes RI,2018) . Profil Kesehatan Indonesia. Jakarta

Maksum, Yusro Hadi. 2019. "Kontrasepsi Pria Kombinasi Kondom Dengan Sistem Kalender Merupakan Upaya Penurunan Angka Unmet-Need Kb." Jurnal Kesehatan Metro Sai Wawai 5.1 : 1-9.

Nelson, Anita L., Massaoudi, N. (2016). New Development in Intrauterone DeviceUse : Focus on The US. Open Acces Journal of Contraception. Vol 7 (127-141)

Perwakilan Badan Kependudukan dan Keluarga Berencana Nasional. 2018 .BKKBN 2018

Pratama, R. Putri. Oktaria D. (2016).Efektivitas Intrauterine Device (IUD) SebagaiAlat Kontrasepsi. Majority. Vol 5 (138-141)

Putri, Rani Pratama. 2017 "Perbandingan Faktor-Faktor Yang Mempengaruhi Penggunaan Kontasepsi Intra Uterine Devices (Iud) Dan Kontrasepsi Implant Pada Wanita Usia Subur Di Kecamatan Sukarame Kota Bandarlampung." Lampung.

Pipit Sri Estuning Rahayu. 2016. Hubungan waktu pemasangan IUD pasca plasenta dan interval dengan kejadian ekspulsi IUD di Kabupaten Mojokerto.Fakultas Kedokteran Universitas Airlangga

Saifuddin AB. 2013. Buku panduan praktis pelayanan kontrasepsi. Jakarta: Yayasan Bina Pustaka;. 
Sety, Laode Muhamad. 2016. "Jenis Pemakaian Kontrasepsi Hormonal Dan Gangguan Menstruasi Di Wilayah Kerja Puskesmas." Jurnal Kesehatan 5.1

Setiawati, Erna, Oktia Woro Kasmini Handayani, And Asih Kuswardinah. 2017. "Pemilihan Kontrasepsi Berdasarkan Efek Samping Pada Dua Kelompok Usia Reproduksi." Unnes Journal Of Public Health 6.3: 167-173.

Ramdhan, Rebecca C., et al. 2018. "Complications of subcutaneous contraception: A Review." Cureus 10.1

Ramli, Risnawati, Nur Ainun Basry, and Maryanti Fidmatan.2020. "Sterilization Study: Vasectomy and Tubectomy." Journal La Medihealtico 1.1 34-38. 